\title{
Possible sister groups and phylogenetic relationships among selected North Pacific and North Atlantic Rhodophyta
}

\author{
Sandra C. Lindstrom* \\ Huntsman Marine Laboratory; St. Andrews, New Brunswick, Canada EOG 2XO
}

\begin{abstract}
Although the cool temperate (boreal) waters of the N. Pacific and N. Atlantic share many similar if not identical species, there have been few studies to test the identity of these species pairs. Whereas such tests are important from a taxonomic perspective, they tell us little if anything about biogeographic relationships. A more useful approach is one employing phylogenetic systematics (cladistics). The interpretation of phylogenetic diagrams (cladograms) in terms of biogeographic area relationships is explained. It is argued that cladistic analyses of taxa occurring in the cool temperate waters of the northern oceans can provide biogeographic tracks, which in turn can suggest the origins and migrations of species and possibly even floras. A number of cool temperate taxa that appear particularly amenable to this approach are discussed, including genera in the Palmariaceae, Corallinaceae, Dumontiaceae, Solieriaceae, Petrocelidaceae, Ceramiaceae and Rhodomelaceae.
\end{abstract}

\section{INTRODUCTION}

The cool temperate, or boreal, waters of the N. Pacific and N. Atlantic share many genera and even some species of red algae in common (Simmons, 1906; van den Hoek, 1975,1984 ), but there have been few studies of the relationships between taxa common to the two oceans. Below, I explore several approaches to the study of possible sister groups and phylogenetic relationships among red algal taxa occurring in these waters.

For purposes of this study, boreal waters are defined largely on the basis of areas of floristic discontinuities: in the western Pacific, from northern Honshu northward (i. e. north of the influence of the Kuroshio Current); in the eastern Pacific, from Pt Conception northward (i. e. outside the influence of the Southern California Bight); in the western Atlantic, from Cape Cod northward (i. e. beyond the influence of the Gulf Stream), and in the eastern Atlantic, from northern Portugal northward.

\section{THE TAXONOMIC APPROACH}

In Table 1 are listed pairs of species that have an amphi-Atlantic-Arctic-Pacific cool temperate distribution pattern (Scagel, 1957; Lebednik, 1977; Lee, 1980; Lindstrom, 1977; Lindstrom \& Scagel, 1980; South, 1984; South \& Tittley, 1986). Most of the pairs of species are represented by the same species name in the two oceans. However, some

\footnotetext{
- Current address: 13965 64th Avenue, Surrey, British Columbia, Canada V3W 1 Y7
} 
Table 1. Pairs of closely related species or the same species of red algae that occur in the cool temperate waters of the N. Atlantic, Arctic and N. Pacific

\begin{tabular}{|ll|}
\hline N. Atlantic/Arctic & N. Pacific \\
\hline Callophyllis cristata & Callophyllis cristata \\
Ceramium rubrum & Ceramium rubrum \\
& C. pacificum \\
Choreocolax polysiphoniae & C. Washingtoniensis \\
Clathromorphum circumscriptum & Leachiella pacifica \\
Clathromorphum compactum & Clathromorphum circumscriptum \\
Devaleraea ramentacea & Clathromorphum compactum \\
Dilsea integra & Devaleraea ramentacea \\
Fimbrifolium dichotomum & Dilsea integra \\
Harveyella mirabilis & Fimbrifolium dichotomum \\
Leptophytum laeve & Harveyella mirabilis \\
Lithothamnion glaciale & Leptophytum laeve \\
Membranoptera alata & Lithothamnion glaciale \\
& Membranoptera serrata \\
Pantoneura angustissima & M. setchellii \\
P. baerii & M. spinulosa \\
Phyllophora truncata & Pantoneura juergensii \\
Ptilota plumosa & Phyllophora truncata \\
P. serrata & Ptilota serrata \\
Rhodomela lycopodioides & P. filicina \\
Scagelia pylaisaei & Rhodomela lycopodioides \\
Turnerella pennyi & Scagelia pylaisaei \\
\hline
\end{tabular}

species are known by one name in the $N$. Atlantic and Arctic and a different name in the N. Pacific although the two species appear to be very similar if not identical. The identity of species pairs in the different oceans represents an hypothesis that the specimens recognized by that name are the same species and belong to one reproductive community. In contrast, the nonidentity of species pairs between the $\mathrm{N}$. Atlantic-Arctic and the $\mathrm{N}$. Pacific represents the hypothesis that the specimens identified by these different names belong to different reproductive communities. Species given different names should be distinguishable by a suite of morphological, physiological, and/or biochemical characters. However, none of these hypotheses of identity or nonidentity has been tested, and this remains a fertile area for morphological, biochemical, and culture studies. Of any group of species, the pairs listed in Table 1 are the most likely to represent single species as all have a range that is continuous through the Arctic, or as continuous as a range can be in areas where suitable substratum is frequently lacking and environmental conditions are hostile.

In Table 2, I present a list similar to Table 1 but this time for species that occur in boreal regions of the two sides of the $N$. Atlantic and the $N$. Pacific but that are absent from the Arctic (Chihara, 1975; Abbott \& Hollenberg, 1976; Lindstrom, 1977; Perestenko, 1980; South, 1984). Once again species pairs are represented by those taxa that are hypothesized to be identical (same name) and by those hypothesized to be distinct (different names), and once again, there has been little experimental work to test these 
Table 2. Pairs of closely related species of red algae that occur in the cool temperate waters of the N. Atlantic and N. Pacific but that are absent from the Arctic

\begin{tabular}{|ll|}
\hline N. Atlantic & N. Pacific \\
\hline Antithamnionella floccosa & Antithamnionella pacifica \\
Callocolax neglectus & Callocolax fungiformis \\
Chondrus crispus & Chondrus crispus \\
Dumontia contorta & Dumontia contorta \\
Gloiosiphonia capillaris & Gloiosiphonia capillaris \\
& G. californica \\
Mastocarpus stellatus & Mastocarpus papillatus \\
& M. pacificus \\
& M. jardinii \\
Platoma bairdii & Platoma sp. \\
P. marginifera & Polyides rotundus? \\
Polyides rotundus & Schizymenia dubyi \\
Schizymenia dubyi & S. pacifica \\
& \\
\hline
\end{tabular}

species hypotheses. Since all of these pairs represent examples of disjunction, one might predict that a majority of them will prove to be reproductively distinct, albeit vicariant, species.

Although the species and species pairs in Tables 1 and 2 provide exciting challenges for the systematist, I argue below that they provide little of interest for the biogeographer.

\section{THE PHYLOGENETIC SYSTEMATICS APPROACH}

Brundin (1981, p. 97) has stated, "The first task of the biogeographer will always be that of a cladist, $i$. e. reconstruction of the actual sector(s) of the hierarchy by applying the principles of phylogenetic systematics". Embodied in these principles is the concept that a minimum of three taxa are required to make a meaningful statement about species interrelationships: a single taxon stands by itself; two taxa stand in identical relationship to each other; only with three taxa can we observe that two appear to be more closely related to each other than they are to a third. This closer relationship is recognized by the possession of synapomorphies, i. e. shared derived character states (Hennig, 1979). Of primary importance to biogeographers is the fact that species (or higher taxa) cladograms (i. e. branching diagrams of taxonomic relationships based on synapomorphies) can be translated directly into biogeographic area cladograms simply by replacing a taxon with the area in which it occurs. Below, I illustrate this concept with an example from the red algal family Dumontiaceae [Humphries \& Parenti (1986) have recently published a monograph in which they clearly and concisely explain the methods of cladistic biogeography using examples from other groups of plants and animals].

Among the species of Dumontiaceae, there is one example of four closely related species in which one species occurs in each of the four boreal areas described in the Introduction (Lindstrom, 1988, in press). These species (and their distributions) are Dilsea carnosa (Schmidel) Kuntze (NE Atlantic), Dilsea integra (Kjellman) Rosenv. (NW Atlantic and Arctic), Dilsea californica (J. Ag.) Kuntze (NE Pacific), and Neodilsea yendoana 


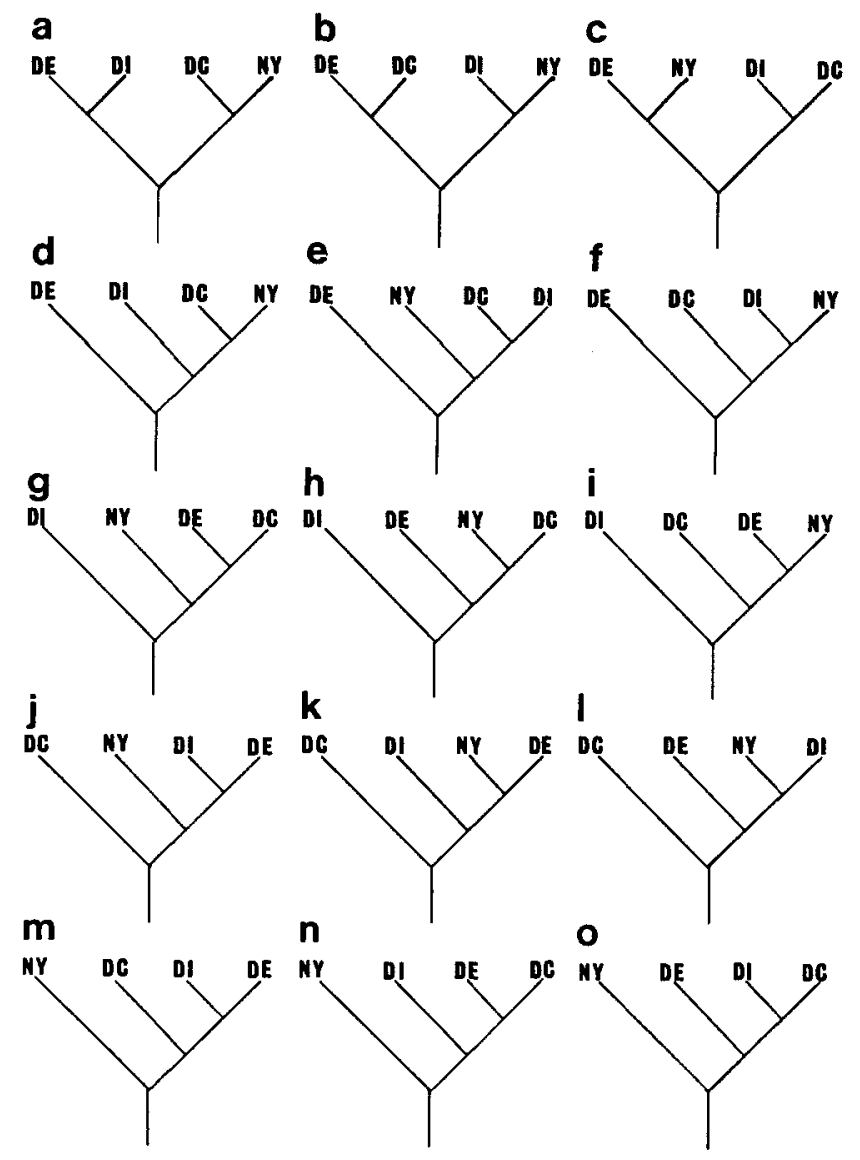

Fig. 1. Fifteen possible phylogenetic relationships among the species Dilsea carnosa (DE), Dilsea integra (DI), Dilsea californica (DC), and Neodilsea yendoana (NY)

Tokida (NW Pacific). Among these four species, there are 15 possible phylogenetic relationships. These are diagramed in Figure 1.

As indicated above, taxonomic cladograms are directly translatable into area cladograms. Figure 2 shows the area cladograms equivalent to the taxonomic cladograms in Figure 1. In general terms, Figure 2a hypothesizes that the cool temperate floras of the NE Atlantic and NW Atlantic (and Arctic) on the one hand and the NE Pacific and the NW Pacific on the other had a more recent common ancestral flora than the cool temperate floras of any other combination of sides of these oceans - not an unreasonable hypothesis given current geography. In contrast, Figure $2 \mathrm{~b}$ hypothesizes that the eastern shores of the two oceans on the one hand and the western shores of the two oceans on the other had a more recent common ancestral flora than any other combination - this hypothesis appears to be geographically absurd. Figure $2 \mathrm{~d}$ also appears to merit consideration. It hypothesizes that the two sides of the Pacific Ocean are most closely related - not unreasonable considering the geographical proximity of Alaska and Siberia and the nearly continuous island arc along the northern rim of the Pacific. This flora is then more 


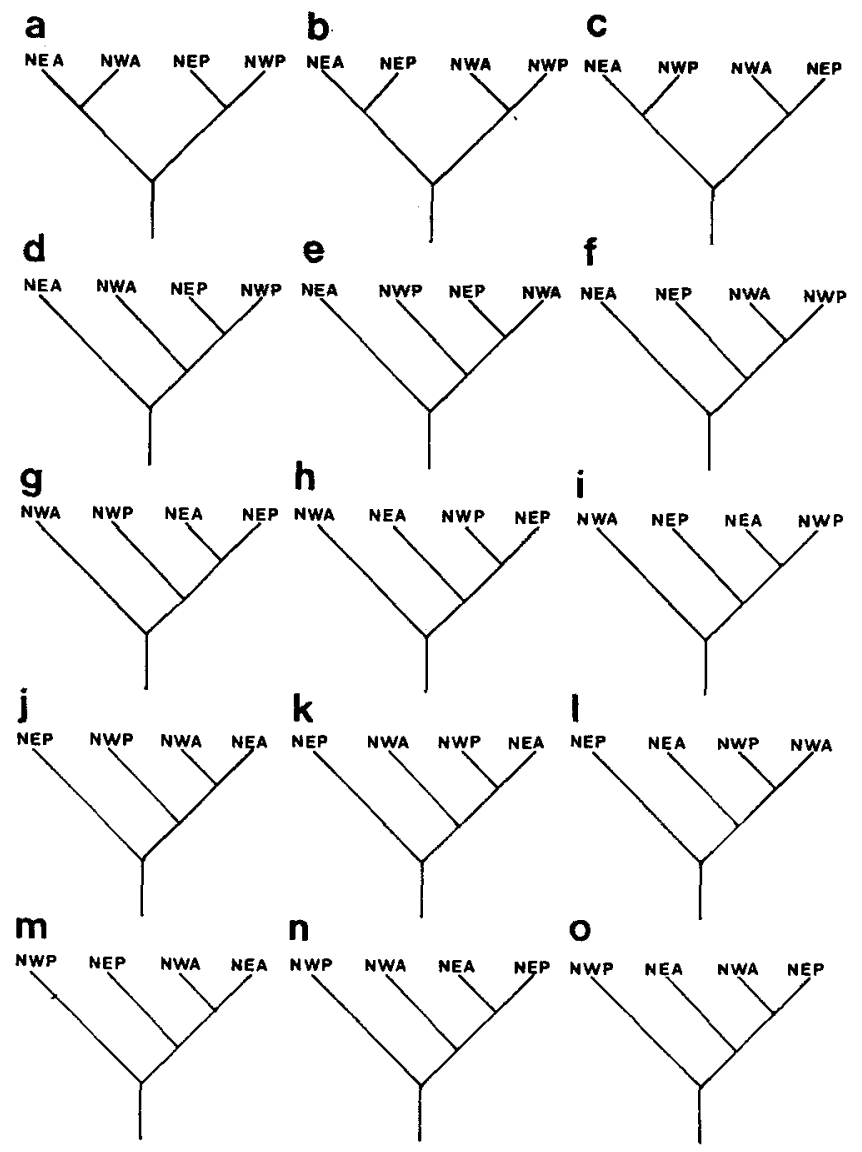

Fig. 2. Fifteen possible biogeographic area relationships corresponding to the phylogenetic relationships depicted in Fig. 1. NEA = Northeast Atlantic (Dilsea carnosa), NWA = Northwest Atlantic (and Canadian Arctic, Dilsea integra), NEP = Northeast Pacific (Dilsea californica), NWP $=$ Northwest Pacific (Neodilsea yendoana)

closely related to that of the NW Atlantic, with the NE Atlantic being most distantly related - also not unreasonable, the Scotian arc connecting Scotland and Greenland having subsided beneath the photic zone during the Miocene or possibly Pliocene (McKenna, 1983; Thiede \& Eldholm, 1983). Similar scenarios can be elaborated for the remaining cladograms in Figure 2.

To resolve which diagram represents the relationships of the floras of the respective sides of oceans, we must obtain congruent results from taxonomic cladograms for a number of different groups of organisms. In the case of Dilsea and Neodilsea, the taxonomic cladogram supported by the data is Figure 1d (Lindstrom, 1988, in press), and hence the area cladogram supported by the taxomomic cladogram is Figure 2d. It should also be borne in mind that the Dilsea-Neodilsea complex does not stand in phylogenetic or geographic isolation $;$ the entire complex has its roots in boreal waters of the N. Pacific (Lindstrom, 1988, in press). In order to make biogeographic generalizations, however, a 
much more sweeping approach is needed. Other groups of species and higher taxa showing a cool temperate boreal distribution must be examined from a similar phylogenetic perspective to determine- whether they display congruent biogeographic patterns, a situation Croizat (1964) and Croizat et al. (1974) have termed "tracks". Table 3 lists groups of red algae that I believe would be particularly profitable to examine from a phylogenetic systematics (sensu Hennig, 1979) perspective. All are cool temperate, and all have members in both the N. Atlantic and N. Pacific.

The family Palmariaceae included Palmaria, Halosaccion, and Leptosarca when established (Guiry, 1974). Devaleraea was segregated from Halosaccion by Guiry (1982), and Lee \& Kurogi (1978) added Neohalosacciocolax. With the exception of Leptosarca, an antiboreal/subantarctic genus, the members of the family are distinctly boreal in distribution. Although the identity of disjunct populations of at least one species of Palmaria has been tested (Van der Meer, 1987), no effort has been made to assess the phylogenetic relationships among these distinctive but obviously closely related species. At least four species are recorded from the N. Pacific: $P$. hecatensis Hawkes, $P$. marginicrassa I. K. Lee, $P$. mollis (Setchell et Gardner) van der Meer et Bird and P. stenogona (Perestenko) Perestenko/P. callophylloides Hawkes, but only one from the N. Atlantic, P. palmata (Linnaeus) Stackhouse. These species of Palmaria are currently being studied electrophoretically in order to propose a hypothesis of phylogenetic relationships among them.

Table 3. Species and higher taxa of red algae that would be particularly amenable to cladistic analyses and comparison of biogeographic tracks

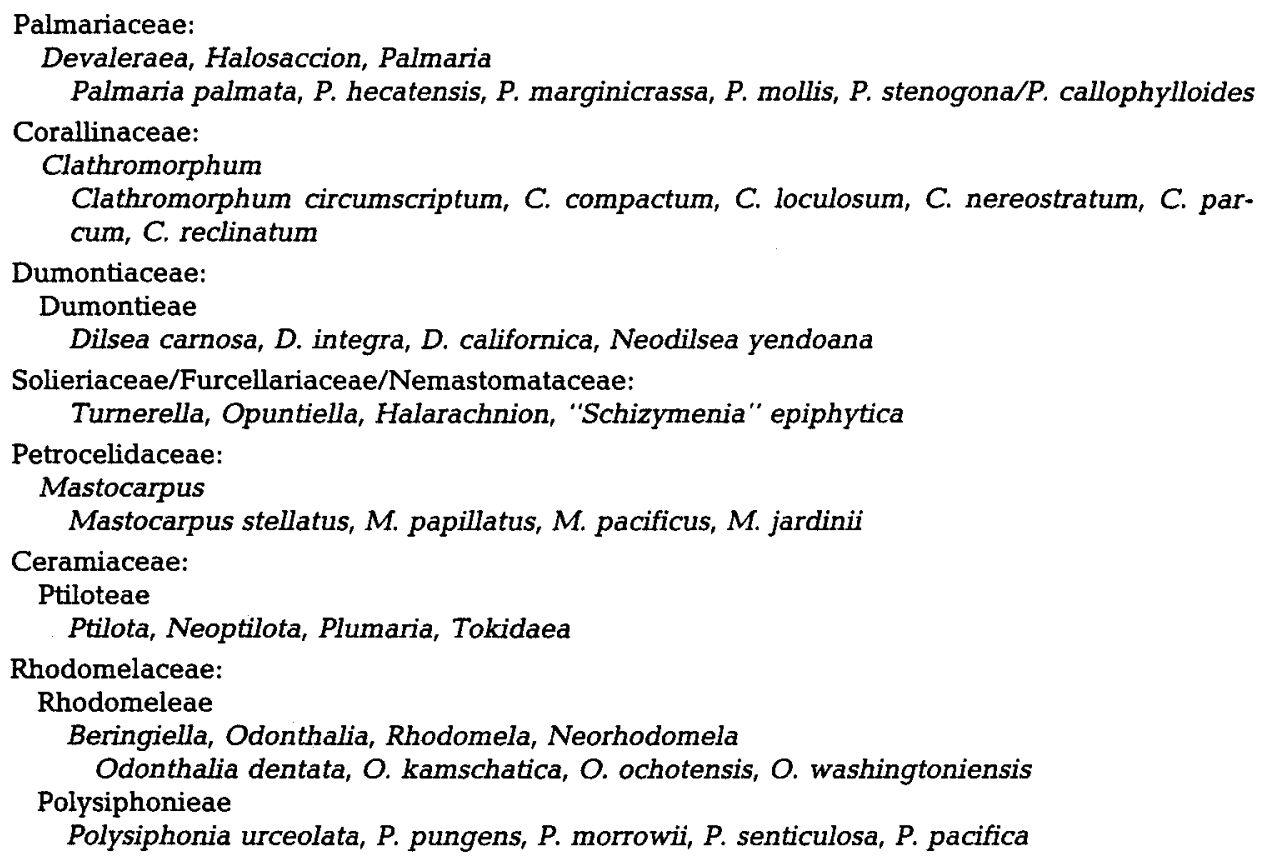




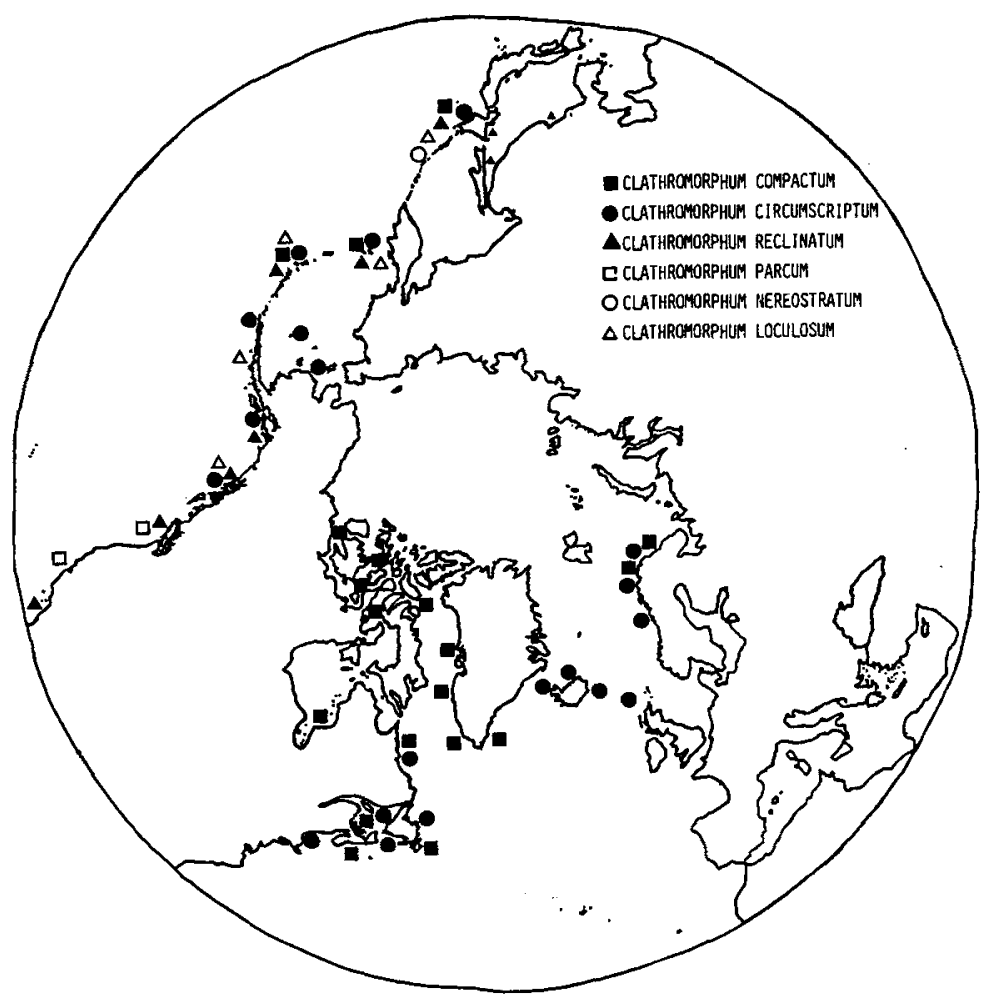

Fig. 3. Distributions of the species of Clathromorphum (Corallinaceae)

The genus Clathromorphum provides an example within the Corallinaceae for which a phylogenetic hypothesis has been proposed (Lebednik, 1977). Although Lebednik does not use the argumentation scheme of phylogenetic systematics sensu Hennig (1979), his work does provide a basis on which a more objective analysis can be carried out. Lebednik has speculated that Clathromorphum first appeared in the Bering Sea. A cladistic analysis of the genus would help resolve this question. The distributions of the species of Clathromorphum are shown in Figure 3. Of the six species in the genus, four [C. loculosum (Kjellman) Foslie, C. nereostratum Lebednik, C. parcum (Setchell et Foslie) Adey and C. reclinatum (Foslie) Adey] are restricted to the N. Pacific and adjacent seas; C. circumscriptum (Stroemfelt) Foslie and C. compactum (Kjellman) Foslie occur in both the N. Pacific and N. Atlantic as well in Arctic regions.

Species of the tribe Dumontieae of the Dumontiaceae are mostly boreal in distribution. Of the 15 species included in this tribe (Lindstrom, 1988, in press), 13 occur in the N. Pacific and adjacent seas and only three in the N. Atlantic - Dumontia contorta (Gmelin) Ruprecht, Dilsea carnosa and D. integra. Although the occurrence of Dumontia contorta in both the N. Atlantic and the N. Pacific is an interesting problem to the systematist (see Table 2 - are the populations in the two oceans really the same species?), it cannot provide the same insight into biogeographic patterns as can the phylogenetic relation- 


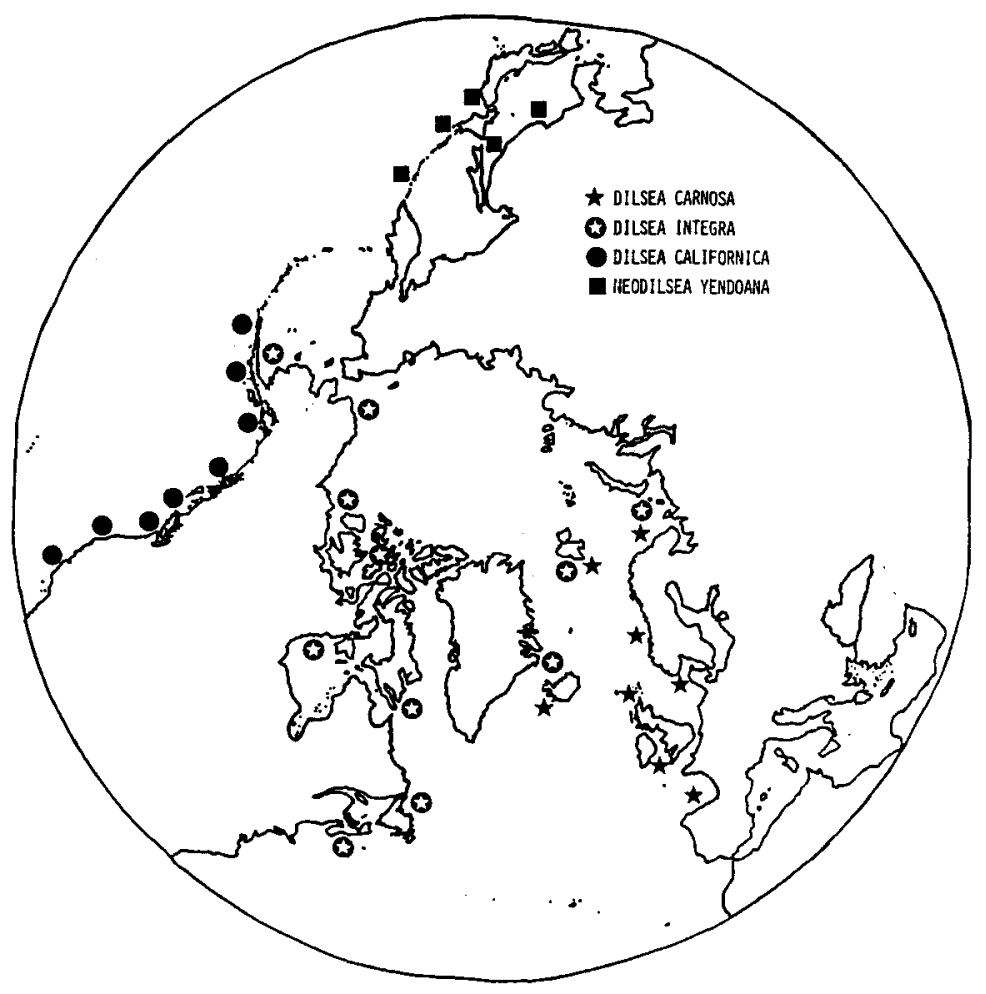

Fig. 4. Distribution of Dilsea carnosa, Dilsea integra, Dilsea californica and Neodilsea yendoana

ships among Dilsea carnosa, D. integra, D. californica and Neodilsea yendoana; the distributions of these species are shown in Figure 4.

Opuntiella and Turnerella are closely related boreal genera currently placed in the Solieriaceae. The macroscopic thallus is a monoecious or dioecious gametophyte. It alternates with a gland-cell containing, Cruoria-like crust (South et al., 1972; Kasahara, 1980; Lindstrom et al., 1986). The gonimoblast develops inwardly. All of these features are shared with Halarachnion ligulatum (Woodward) Kuetzing, a member of the Furcellariaceae (Kylin, 1956) (Whether all of these features are also shared by the two Japanese species of Halarachnion, $H$. latissimum Okamura and $H$. parvum Yamada, is unknown). It is not known whether these features represent symplesiomorphies (shared primitive characters), synapomorphies, or instances of parallel evolution. Further morphological and biochemical studies should help resolve this question. The distributions of Opuntiella californica (Farlow) Kylin, Turnerella mertensiana (Postels et Ruprecht) Schmitz, T. pennyi (Harvey) Schmitz, Halarachnion ligulatum and Schizymenia epiphytica (Setchell et Lawson) Smith et Hollenberg, a similar species in the Nemastomataceae, are shown in Figure 5. The distributions of Opuntiella ornata (Postels et Ruprecht) A. Zinova (1972), recorded from the Kamchatka Peninsula and Bering Island in the NW Pacific, and Turnerella glaphyra Perestenko (1976), recorded from the Okhotsk Sea, are not shown. 


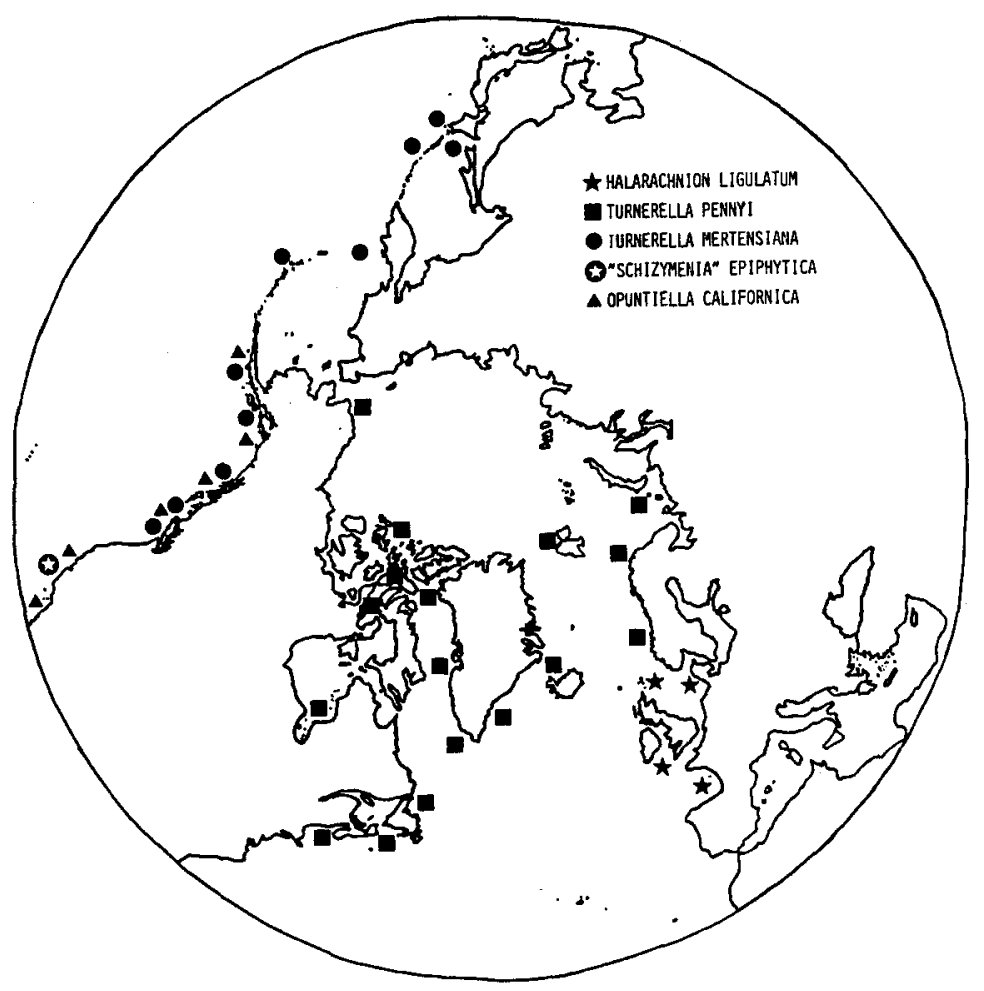

Fig. 5. Distributions of Halarachnion ligulatum, Turnerella pennyi, T. mertensiana, "Schizymenia" epiphytica and Opuntiella californica

Mastocarpus in the Petrocelidaceae represents another example of a taxon showing a predominantly cool temperate boreal distribution (Fig. 6) although at least one species is also known to occur in Chile (see Guiry et al., 1984; p. 58). Four species [Mastocarpus stellatus (Stackhouse) Guiry, M. papillatus (C. Agardh) Kuetzing, M. jardinii (J. Agardh) $J$. A. West and $M$. pacificus (Kjellman) Perestenkol are currently recognized. The alpha taxonomy of this complex has been confirmed largely through much elegant culture work (Chen et al., 1974; Dion \& Delépine, 1979; Guiry \& West, 1984; Masuda \& Kurogi, 1981; Masuda \& Uchida, 1976; Masuda et al., 1984; Polanshek \& West, 1976, 1977; West, 1972; West et al., 1977, 1979). Although more breeding data exist for this complex than for any other group of closely related red algae, no explicit hypothesis of phylogenetic relationships among the species of Mastocarpus has been proposed. The lack of a phylogenetic hypothesis reflects in part the limitation of culture studies in assessing evolutionary relationships: the ability to interbreed is a plesiomorphic condition derived from a time when individuals belonged to the same species. Sometimes individuals in different species and even genera have maintained the ability to interbreed. However, once the ability to interbreed is lost, even this primitive information disappears.

Several tribes or other species assemblages in the Ceramiales show distinct boreal or boreal-arctic distributions. The Ptiloteae [if southern hemisphere representatives of Kylin 


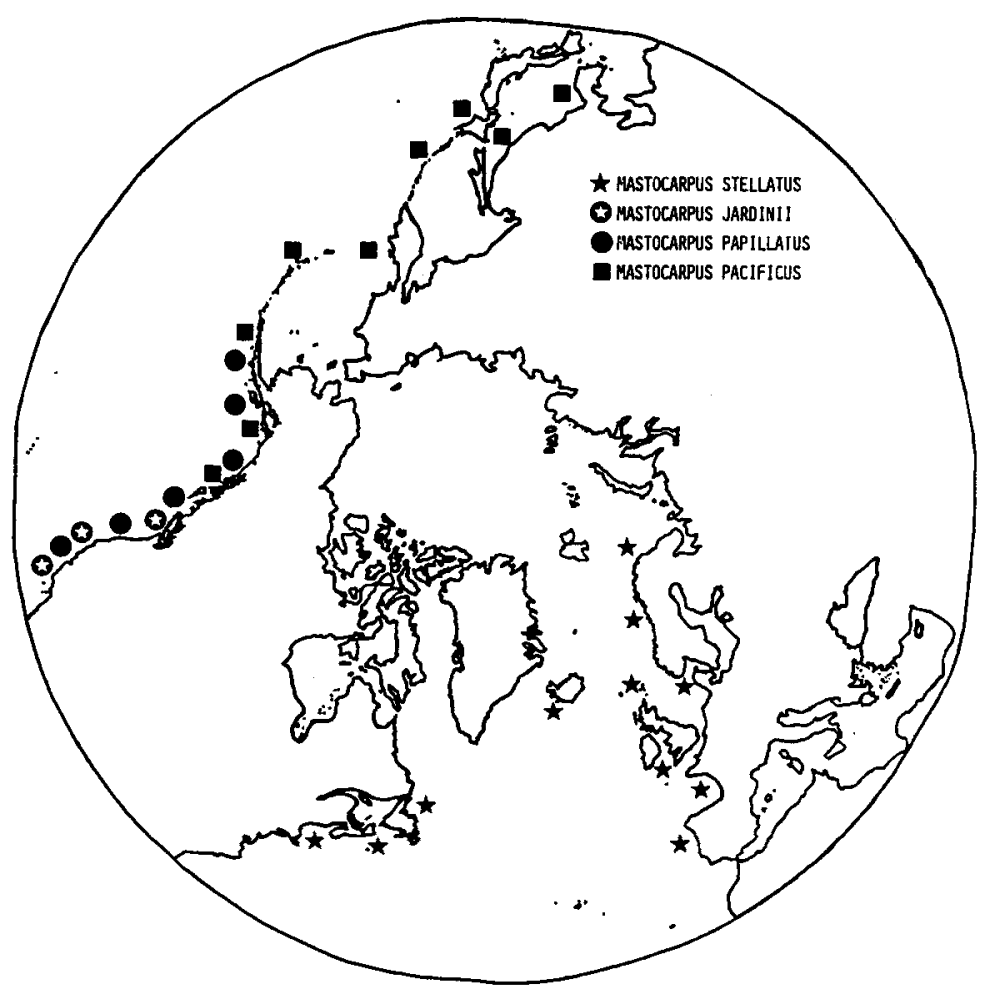

Fig. 6. Distributions of Mastocarpus stellatus, M. jardinii, M. papillatus and M. pacificus

(1956) are excluded - see Moe \& Silva $(1979,1983)$ and Lindstrom \& Wynne (1982)] is composed largely of species and genera showing this pattern. The distributions of Plumaria, Ptilota, Neoptilota and Tokidaea are shown in Figure 7. These taxa represent another relatively well-defined group that would be highly amenable to a phylogenetic systematics study.

The Rhodomeleae in the Rhodomelaceae provides another example of an assemblage of related boreal genera. Beringiella, Odonthalia, Rhodomela, and Neorhodomela are restricted to boreal waters of the N. Pacific and/or N. Atlantic. As a result of the recent studies of Masuda (1981a, 1981b, 1982; Masuda \& Shimizu, 1980; Masuda \& Yamada, 1980,1981 ) and Wynne (1980b), the species and genera appear to be well circumscribed, providing an ideal situation for initiating a phylogenetic systematics study. In Figure 8, I show the distributions of four costate species of Odonthalia [O. dentata (Linnaeus) Lyngbye, $O$. kamschatica (Ruprecht) J. Agardh, O. ochotensis (Ruprecht) J. Agardh, and $O$. washingtoniensis Kylin] whose relationships in particular might provide useful insights into biogeographical area relationships. All but $O$. washingtoniensis have calcars, the spurlike tip of the branch bearing the cystocarp. Cystocarps range from urceolate in $O$. kamschatica and $O$. ochotensis to pitcher-shaped in $O$. dentata to round in O. washingtoniensis (which may represent a character transformation series), and all but O. kamschatica have relatively small, corymbosely arranged cystocarps. 


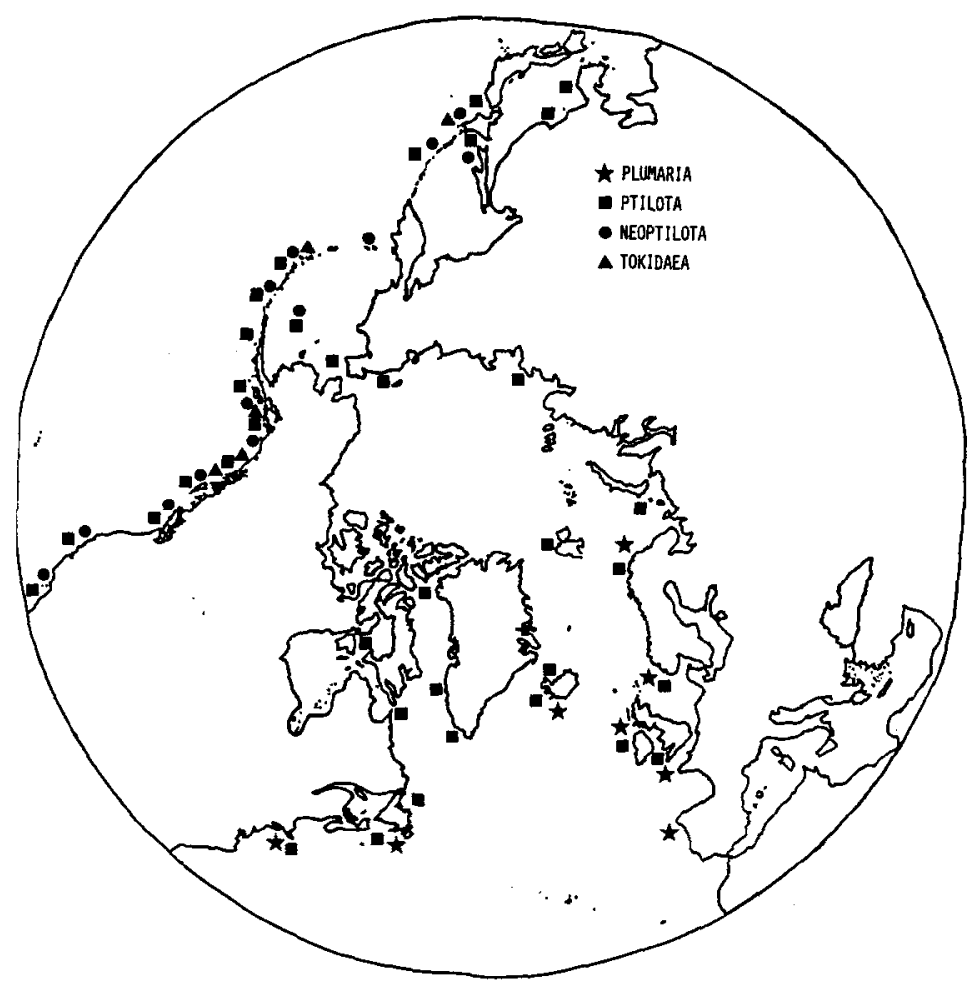

Fig. 7. Distributions of species of Plumaria, Ptilota, Neoptilota, and Tokidaea

Part of the genus Polysiphonia (also Rhodomelaceae), including several species assigned to the genus Orcasia (Kylin, 1941), also appears to represent a complex of closely related, boreal species. Polysiphonia urceolata (Dillwyn) Greville, P. pungens Hollenberg, P. morrowii Harvey, P. senticulosa Harvey, and at least some varieties of $P$. pacifica Hollenberg all have four pericentral cells, are ecorticate, with trichoblasts and/ or scar cells rare or lacking, (some) branches arising endogenously, urceolate cystocarps, and tetrasporangia about $75 \mu \mathrm{m}$ in diameter in longitudinal series.

\section{CONCLUSIONS}

Although Brundin (1981) has indicated that we must establish hypotheses of phylogenetic relationships before we can create our biogeographic hypotheses, several biogeographic hypotheses already exist. Among zoologists, it is commonly conceded that there was a net migration of cool temperate species from the Pacific Ocean into the Atlantic during the Pliocene (e. g. Briggs, 1974; Franz \& Merrill, 1980). Ekman (1953) believed that, "During the whole of the Tertiary Period the North Pacific offered much more favourable conditions for the development of a fauna adapted to a cold-temperate climate than the North Atlantic". Lüning (1985) has questioned whether the endemic 


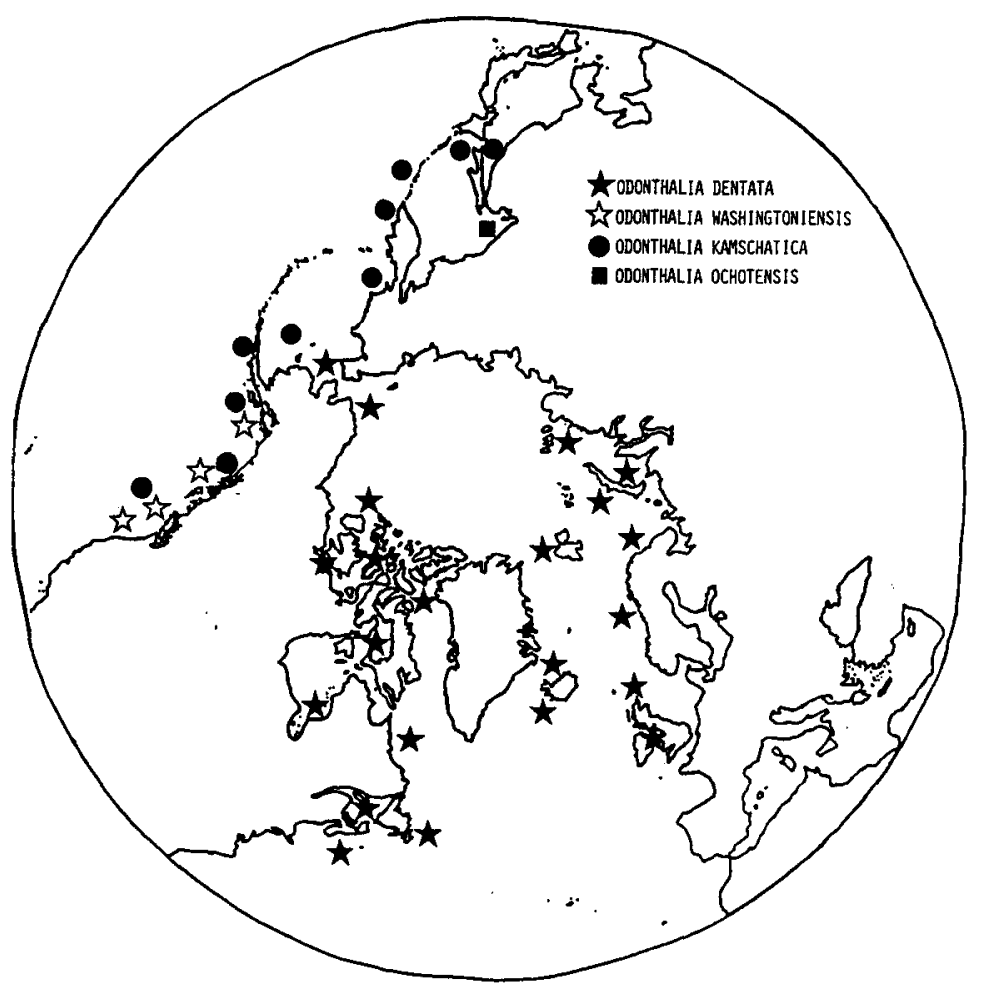

Fig. 8. Distributions of Odonthalia dentata, O. washingtoniensis, $O$. kamschatica and $O$. ochotensis

N. Atlantic Arctic-cold temperate species originated there or are derived from N. Pacific ancestors.

Van den Hoek (1984) found 21 of 29 cool temperate red algal genera that occur in the Arctic and cool temperate $\mathrm{N}$. Atlantic are shared with the cool temperate $\mathrm{N}$. Pacific. A list of the endemic cool temperate genera and higher level taxa in the N. Pacific can be found in Table 4 (Abbott \& Hollenberg, 1976; Adey et al., 1974; Chihara, 1975; Hansen \& Lindstrom, 1984; Kylin, 1956; Lee \& Kurogi, 1978; Lindstrom, 1987; Lindstrom \& Wynne, 1982; Masuda, 1976; Perestenko, 1975; Scagel, 1957; Wynne, 1970a, 1970b, 1980a, 1983; Wynne et al., 1973; Wynne \& Norris, 1982; and Yoshida et al., 1985). Table 5 lists genera of cool temperate red algae endemic to the N. Atlantic (Kylin, 1956; South \& Tittley, 1986); there are no endemic higher level taxa. A comparison of Tables 4 and 5 reveals that the Pacific Ocean provides a much richer source area for species than the N. Atlantic. The extent of the list of cool temperate N. Pacific endemics (including taxa recognized at the tribal or even familial level) and the apparent ability of many genera to invade the Arctic during the late Pliocene as the Bering Land Bridge was inundated suggest that a boreal flora already existed in the N. Pacific prior to 3 million years ago. Did this flora provide the seed stock for what appear to be closely related species in the Arctic and cool temperate North Atlantic? Cladistic analyses of a number of species complexes or related genera can provide the biogeographic tracks that we need to test whether this is a 
Table 4. Genera and higher taxa of red algae endemic to cool temperate waters of the N. Pacific

\begin{tabular}{|ll|}
\hline Beringia & Kallymeniopsis \\
Beringiella & Kurogia \\
Boreothamnion & Kurogia Group \\
Chiharaea & Mikamiella \\
Cirrulicarpus * & Neoabbottiella \\
Congregatocarpus & Neodilsea \\
Congregatocarpus Group & Neohalosacciocolax \\
Constantinea & Neohypophyllum \\
Crossocarpus & Orculifilum \\
Crossocarpaceae & Pleuroblepharidella \\
Cryptosiphonia & Polyneuropsis \\
Cumathamnion & Rhodophysemopsis \\
Erythrophyllum & Schizoclaenion \\
Ezo & Thuretellopsis \\
Faucheocolax & Tichocarpus \\
Halosaccion & Tokidadendron \\
Heteroglossum & Tokidaea \\
Hideophyllum & Whidbeyella \\
Hollenbergia & Yamadaphycus \\
Hommersandia & Yendonia \\
& Zinovaea \\
- Although species of Cirrulicarpus have been recorded from outside the N. Pacific, these \\
species should be placed in other genera.
\end{tabular}

Table 5. Genera of red algae endemic to cool temperate waters of the N. Atlantic

$\begin{array}{ll}\text { Ceratocolax } & \text { Halosacciocolax } \\ \text { Furcellaria } & \text { Kvaleya }\end{array}$

tenable hypothesis. Until we adopt such a rigorous approach to questions of biogeographic origins or affinities, we will be indulging merely in idle speculation.

Acknowledgements. Financial support from the Biologische Anstalt Helgoland and from NSERCC Grant A-2204 to Dr. G. R. South to allow the author's participation in the Seaweed Biogeography Workshop is gratefully acknowledged. Drs. P. W. Gabrielson, M. D. Guiry, and G. R. South provided helpful comments on an earlier version of this paper. I especially want to thank Dr. K. Lüning for inviting me to the workshop and for providing many stimulating discussions.

\section{LITERATURE CITED}

Abbott, I. A. \& Hollenberg, G. J., 1976. Marine algae of California. Stanford Univ. Press, Stanford, Calif., $827 \mathrm{pp}$.

Adey, W. H., Masaki, T. \& Akioka, H., 1974. Ezo epiyessoense, a new parasitic genus and species of Corallinaceae (Rhodophyta, Cryptonemiales). - Phycologia 13, 329-344.

Briggs, J. C., 1974. Marine zoogeography. McGraw-Hill, New York, 475 pp.

Brundin, L. Z., 1981. Croizat's panbiogeography versus phylogenetic biogeography. In: Vicariance biogeography. Ed. by G. Nelson \& D. E. Rosen. Columbia Univ. Press, New York, 94-138. 
Chen, L. C.-M., Edelstein, T. \& McLáchlan, J., 1974. The life history of Gigartina stellata (Stackh.) Batt. (Rhodophyceae, Gigartinales) in culture. - Phycologia 13, 287-294.

Chihara, M., 1975. Seaweeds. Gakken, Tokyo, 290.pp (in Japan.).

Croizat, L., 1964. Space, time, form: the biological synthesis. Croizat, Caracas, 881 pp.

Croizat, L., Nelson, G. \& Rosen, D. E., 1974. Centers of origin and related concepts. - Syst. Zool. 23, 265-287.

Dion, P. \& Delépine, R., 1979. Cycles de développement de Gigartina stellata et Petrocelis cruenta (Rhodophyceae, Gigartinales) étudiés in situ à Roscoff. - Revue algol. (N. S.) 14, 327-341.

Ekman, S., 1953. Zoogeography of the sea. Sidgwick \& Jackson, London, $417 \mathrm{pp}$.

Franz, D. R. \& Merrill, A. S., 1980. The origins and determinants of distribution of molluscan faunal groups on the shallow continental shelf of the northwest Atlantic. - Malacologia 19, 227-248.

Guiry, M.D., 1974. A preliminary consideration of the taxonomic position of Palmaria palmata (Linnaeus) Stackhouse $=$ Rhodymenia palmata (Linnaeus) Greville. - J. mar. biol. Ass. U. K. 54, $509-528$.

Guiry, M. D., 1982. Devaleraea, a new genus of the Palmariaceae (Rhodophyta) in the North Atlantic and North Pacific. - J. mar. biol. Ass. U. K. 62, 1-13.

Guiry, M. D. \& West, J. A., 1984. Life history and hybridization studies on Gigartina stellata and Petrocelis cruenta (Rhodophyta) in the North Atlantic. - J. Phycol. 19, 474-494.

Guiry, M. D., West, J. A., Kim, D.-H. \& Masuda, M., 1984. Reinstatement of the genus Mastocarpus Kützing (Rhodophyta). -Taxon 33, 53-63.

Hansen, G. I. \& Lindstrom, S. C., 1984. A morphological study of Hommersandia maximicarpa gen. et sp. nov. (Kallymeniaceae, Rhodophyta) from the North Pacific. - J. Phycol. 20,476-488.

Hennig, W., 1979. Phylogenetic systematics. Univ. of Mllinois Press, Urbana, $263 \mathrm{pp}$.

Hoek, C. van den, 1975. Phytogeographic provinces along the coasts of the northern Atlantic Ocean. - Phycologia 14, 317-330.

Hoek, C. van den, 1984. World-wide latitudinal and longitudinal seaweed distribution patterns and their possible causes, as illustrated by the distribution of Rhodophytan genera. - Helgoländer Meeresunters. 38, 227-257.

Humphries, C. J. \& Parenti, L. R., 1986. Cladistic biogeography. Clarendon Press, Oxford, 98 pp.

Kasahara, K., 1980. On the life history of Turnerella mertensiana (Rhodophyta, Gigartinales). - Bot. Mag. Tokyo 93, 117-123.

Kylin, H., 1941. Californische Rhodophyceen. - Lunds Univ. Arsskr. (N. F., Avd. 2) 37 (2), 1-51.

Kylin, H., 1956. Die Gattungen der Rhodophyceen. Gleerups, Lund, 673 pp.

Lebednik, P. A., 1977. The Corallinaceae of northwestern North America I. Clathromorphum Foslie emend. Adey. - Syesis 9, 59-112.

Lee, I. K. \& Kurogi, M., 1978. Neohalosacciocolax aleutica gen. et sp, nov. (Rhodophyta), parasitic on Halosaccion minjaii I.K. Lee from the north Pacific. - Br. phycol. J. 13, 131-139.

Lee, R. K. S., 1980. A catalogue of the marine algae of the Canadian Arctic. - Natn. Mus. Can. Publ. Bot. 9, 1-82.

Lindstrom, S. C., 1977. An annotated bibliography of the benthic marine algae of Alaska. - Tech. Data Rep. Alaska Dep. Fish Game 31, 1-172.

Lindstrom, S. C., 1987. Orculifilum denticulatum (Dumontiaceae, Rhodophyta), a new genus and species from the northeast Pacific. - Phycologia 26, 129-137.

Lindstrom, S. C., 1988. The Dumontieae, a resurrected tribe of red algae (Dumontiaceae, Rhodophyta). - Phycologia 27 (in press).

Lindstrom, S. C. \& Scagel, R. F., 1980. Some new distribution records of marine algae in southeast Alaska. - Syesis 12, 163-168.

Lindstrom, S. C. \& Wynne, M. J., 1982. Tokidaea chilkatensis sp. nov. and T. serrata (Wynne) comb. nov. (Ceramiaceae, Rhodophyta) from Alaska. - Syesis 14, 33-43.

Lindstrom, S. C., Calvin, N. I. \& Ellis, R. J., 1986. Benthic marine algae of the Juneau, Alaska area. Contr. nat. Sci. (B. C. Prov. Mus.) 6, 1-10.

Lüning, K., 1985. Meeresbotanik. Thieme, Stuttgart, 375 pp.

Masuda, M., 1976. Taxonomic notes on Rhodophysemopsis gen. nov. (Rhodophyta). - J. Jap. Bot. 51 , 175-187.

Masuda, M., 1981a. Odonthalia kawabatae sp. nov. (Rhodophyta, Rhodomelaceae) from the Kuril Islands. - Jap. J. Phycol. 29, 151-156. 
Masuda, M., 1981b. Taxonomic notes on Odonthalia lyallii (Harvey) J. Agardh and related species (Rhodophyta). - J. Fac. Sci., Hokkaido Univ. (Ser. 5: Bot.) 12, 147-158.

Masuda, M., 1982. A systematic study of the tribe Rhodomeleae (Rhodomelaceae, Rhodophyta). - J. Fac. Sci., Hokkaido Univ. (Ser. 5: Bot.) 12, 209-400.

Masuda, M. \& Kurogi, M., 1981. The life history of Gigartina ochotensis (Ruprecht) Ruprecht (Rhodophyta) in culture. - J. Fac. Sci., Hokkaido Univ. (Ser: 5 Bot.) 12, 165-171.

Masuda, M. \& Shimizu, T., 1980. Taxonomic notes on Rhodomela lycopodioides (L.) C. Ag. f. tenuissima (Rupr.) Kjellm. (Rhodophyta). - Jap. J. Phycol. 28, 241-248.

Masuda, M. \& Uchida, T., 1976. On the life history of Gigartina ochotensis (Rupr.) Rupr. from Muroran, Hokkaido. - Bull. Jap. Soc. Phycol. 24, 41-47.

Masuda, M. \& Yamada, I., 1980. Identity of Odonthalia aleutica sensu Okamura. - Jap. J. Phycol. 28, 183-189.

Masuda, M. \& Yamada, I., 1981. Taxonomic notes on Odonthalia ochotensis (Rupr.) J. Ag. and $O$. kamschatica (Rupr.) J. Ag. (Rhodophyta). - Acta Phytotax. Geobot. 32, 165-173.

Masuda, M., West, J., Ohno, Y. \& Kurogi, M., 1984. Comparative reproductive patterns in culture of different Gigartina subgenus Mastocarpus and Petrocelis populations from northern Japan. Bot. Mag. Tokyo 97, 107-125.

McKenna, M. C., 1983. Cenozoic paleogeography of North Atlantic land bridges. In: Structure and development of the Greenland-Scotland Ridge, new methods and concepts. Ed. by M. H. P. Bott, S. Saxov, M. Talwani \& J. Thiede. Plenum Press, New York, 351-399.

Meer, J. P. van der, 1987. Experimental hybridization of Palmaria palmata (Rhodophyta) from the northeast and northwest Atlantic Ocean. - Can. J. Bot. 65, 1451-1458.

Moe, R. L. \& Silva, P. C., 1979. Morphological and taxonomic studies on Antarctic Ceramiaceae (Rhodophyceae). I. Antarcticothamnion polysporum gen. et sp. nov. - Br. phycol. J. 14, 385-405.

Moe, R. L. \& Silva, P. C., 1983. Morphological and taxonomic studies on Antarctic Ceramiaceae (Rhodophyceae). III. Georgiella and Plumariopsis (Tribe Ptiloteae). - Br. phycol. J. 18, 275-298.

Perestenko, L. P., 1975. The red algae of the Far-Eastern seas of the U.S.S. R. Foliose cryptonemiacean algae (Cryptonemiales, Rhodophyta), - Bot. Zh. 60, 1676-1689 (in Russian).

Perestenko, L. P., 1976. The red algae of the Far-Eastern seas of the U. S. S. R. Turnerella Schmitz, Opuntiella Kyliń (Solieriaceae, Gigartinales). - Nov. sist. nizshikh rast 13, 39-50 (in Russian).

Perestenko, L. P., 1980. Seaweeds of Peter the Great Bay [Vodorosli zaliva petra velikogo]. Akad. Nauk S. S. R., Leningrad, 232 pp (in Russian).

Polanshek, A. R. \& West, J. A., 1976. Culture and hybridization studies on Petrocelis (Rhodophyta) from Alaska and California. - J. Phycol. 11, 434-439.

Polanshek, A. R. \& West, J. A., 1977. Culture and hybridization studies on Gigartina papillata (Rhodophyta). - J. Phycol. 13, 141-149.

Scagel, R. F., 1957. An annotated list of the marine algae of British Columbia and northern Washington. - Bull. natn. Mus. Can. 150, 1-289.

Simmons, H. G., 1906. Remarks about the relations of the floras of the Northern Atlantic, the Polar Sea and the Northern Pacific. - Bot. Zbl. (Beih.) 19, 149-194.

South, G. R., 1984. A checklist of marine algae of eastern Canada, second revision. - Can. J. Bot. 62, $680-704$.

South, G. R., Hooper, R. G. \& Irvine, L. M., 1972. The life history of Turnerella pennyi (Harv.) Schmitz. - Br. phycol. J. 7, 221-233.

South, G. R. \& Tittley, I., 1986. A checklist and distributional index of the benthic marine algae of the North Atlantic Ocean. British Museum (Natural History), London, 76 pp.

Thiede, J. \& Eldholm, O., 1983. Speculations about the paleodepth of the Greenland-Scotland Ridge during late Mesozoic and Cenozoic. In: Structure and development of the Greenland-Scotland Ridge. Ed. by M. H. P. Bott, S. Saxov, M. Talwani \& J. Thiede. Plenum Press, New York, 445-456.

West, J. A., 1972. The life history of Petrocelis franciscana. - Br. phycol. J. 7, 299-308.

West, J. A., Polanshek, A. R. \& Guiry, M. D., 1977. The life history in culture of Petrocelis cruenta J. Agardh (Rhodophyta) from Ireland. - Br. phycol. J. 12, 45-53.

West, J. A., Polanshek, A. R. \& Shevlin, D. E., 1979. Field and culture studies on Gigartina agardhii (Rhodophyta). - J. Phycol. 14, 416-426.

Wynne, M. J., 1970a. Marine algae of Amchitka Island (Aleutian Islands). I. Delesseriaceae. - Syesis 3, 95-144. 
Wynne, M. J., 1970b. Marine algae of Amchitka Isiand (Aleutian Islands). II. Bonnemaisoniaceae. Pacif. Sci. 24, 433-438.

Wynne, M. J., 1980a. Boreothamnion (Ceramiaceae, Ceramiales), a new red algal genus from Alaska. - Contr. Univ. Mich. Herb. 14, 209-219.

Wynne, M. J., 1980b. Beringiella (Rhodomelaceae, Ceramiales), a new red algal genus from Alaska. - Contr. Univ. Mich. Herb. 14, 221-229.

Wynne, M. J., 1983. The current status of genera in the Delesseriaceae (Rhodophyta). - Botanica mar. 26, 437-450.

Wynne, M. J. \& Norris, R. E., 1982. Schizochlaenion gen. nov. (Rhodomelaceae, Ceramiales), a new red algal genus from the northeastern North Pacific. - Phycologia 21, 288-298.

Wynne, M. J., McBride, D. L. \& West, J. A., 1973. Polyneuropsis stolonifera gen. et sp. nov. (Delesseriaceae, Rhodophyta) from the Pacific Coast of North America. - Syesis 6, 243-253.

Yoshida, T., Nakajima, Y. \& Nakata, Y., 1985. Preliminary check-list of marine benthic algae of Japan II. Rhodophyceae. - Jap. J. Phycol. 33, 249-275 (in Japan.).

Zinova, A. D., 1972. New and unusual species of red algae of the Far-Eastern seas of the U.S.S.R. 1. - Nov. sist. nizshikh rast $9,82-87$ (in Russian). 